\title{
Comparative Effect of The Previous Fertilizer and The Use of The Biostimulant Banzaï on the Production of Cherries in the Locality of N'gouanmoinkro in the department of Toumodi, Central Côte d'Ivoire
}

\author{
Hermann-Desiré LALLIE, Mohamed DOUMBOUYA, Franck Zokou ORO
}

\begin{abstract}
Côte d'Ivoire, a West African country, is the world's leading cocoa producer. However, cocoa tree diseases and pests are rampant in all regions and can cause production losses of up to $60 \%$. In order, to minimize production losses, several types ofbiostimulants have been put in place, including the Banzaï biostimulant. The objective of this study is to know the effect of the biostimulant Banzaï and the previous fertilizer on the production of cherries in the locality of N'gouanmoinkro. This study was carried out according to two devices, a device comprising a field of cocoa trees who received a fertilizer input during the last three years (DAE) and another without fertilizer input received during the last three years (DSE) preceding the year of experimentation. The results obtained showed that the plots that received the biostimulant Banzaï produced significantly more cherries than the control plots on which there was no application of the biostimulant. Indeed,compared to the controls, the production rate of cherries is more between 33to $70 \%$ in the plots without unprecedented fertilizer (DSE) and between 23 to $46 \%$ in the plots with previous fertilizer (DAE). However, the production of cherries is more than twice as high in the DAE as in the DSE. This study clearly shows the impact of the use of biostimulants andfertilizers on the yield of cocoa trees and can be used in the fight against the limitation of damage produced by pests and diseases of cocoa trees in Côte d'Ivoire.

Index Terms - Banzaï; Biostimulant; Cocoa; Productivity; Côte d'Ivoire.
\end{abstract}

\section{INTRODUCTION}

The cocoa tree Theobroma cacaoL[1], a tropical species native to Mexico, is a small tree of 5 to 7 meters in medium height, which reaches its full development around the age of 10 years. The cocoa tree produces flowers that as they grow form a young fruit of less than 6 centimeters called cherries, which in turn grows to form a berry called pod that can weigh at maturity between 200 grams and 1 kilogram(Fig.11). This fruit contains on average nearly 30 to 40 cocoa beans [2] used in various fields such as cosmetics, pharmacy and food,

Hermann-Desiré LALLIE, Peleforo GON COULIBALY University, Training and Research Unit (UFR) of Biological Sciences, Department of Chemistry-Genetics, BP 1328 Korhogo, Côte d'Ivoire

Mohamed DOUMBOUYA, ,Peleforo GON COULIBALY University, Training and Research Unit (UFR) of Biological Sciences, Department of Plant Biology, BP 1328 Korhogo, Côte d'Ivoire,

Franck Zokou ORO Peleforo GON COULIBALY University, Training and Research Unit (UFR) of Biological Sciences, Department of Plant Biology, BP 1328 Korhogo, Côte d'Ivoire. particularly in the manufacture of chocolate.In 2017, world cocoa production is estimated at 4,645,000 tons, Africa represents $70 \%$ of this share of the world brown bean market [4].

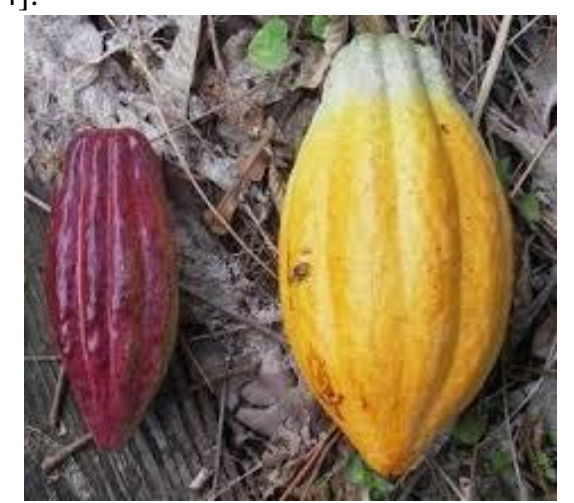

Fig.11: Cherrie (left) and pod (right) of cocoa.[3].

As the world's leading producer, Côte d'Ivoire produced $2,000,000$ tons of cocoa beans in 2018 , or $40 \%$ of global supply [5]. The contribution of cocoa on the Ivorian Gross Domestic Product, employment, land use, production, and trade of Côte d'Ivoire font of this culture the main ofthe country [6].

However, despite its importancein the socio-economic development of Côte d'Ivoire, cocoa cultivation is threatened by cocoa diseases and pests which are rife in all regions [7]. Diseases and pests encountered in cocoa farming include Cocoa Swollen Shoot Disease (CSSD) (Fig.

Fig.2brown podrot (Fig.

Fig.2mirides, cocoa stalk drillers, moniliosis and witch's broom [8-11]. These diseases can cause yield losses of up to $60 \%$ [7].

To limit the impact of all these diseases and pests and also to improve the yield of cocoa cultivation, it is recommended the use of fungicides to limit the impact of fungi, the use of fertilizers for a better fertilization of the soil and a total expression of the potentiality of cocoa trees, and the use of pesticides to curb the spread of harmful insects [12-13]. In addition, in recent years a new category of biological control products has appeared on the market for agricultural inputs [14]. These are biostimulants. These biostimulants are substances or microorganisms whose primary function is the stimulation of the natural processes of plants [14]. They promote and improve the absorption or use of nutrients, 


\section{Comparative Effect of The Previous Fertilizer and The Use of The Biostimulant Banzaï on the Production of Cherries in the Locality of N'gouanmoinkro in the department of Toumodi, Central Côte d'Ivoire}

tolerance to abiotic stresses, the quality or yield of the crop, regardless of the presence of nutrients [15]. This study was conducted to determine the combined effect of the use of the biostimulant Banzai and the previous fertilizer on the production of cocoa trees.Specifically, it will be necessary firstly to determine the optimal number of applications of the biostimulant Banzaï and secondly the impact of the use of the previous fertilizer and the use of the fertilizer during the experiment on the production of cherries in a peasant cocoa plantation.

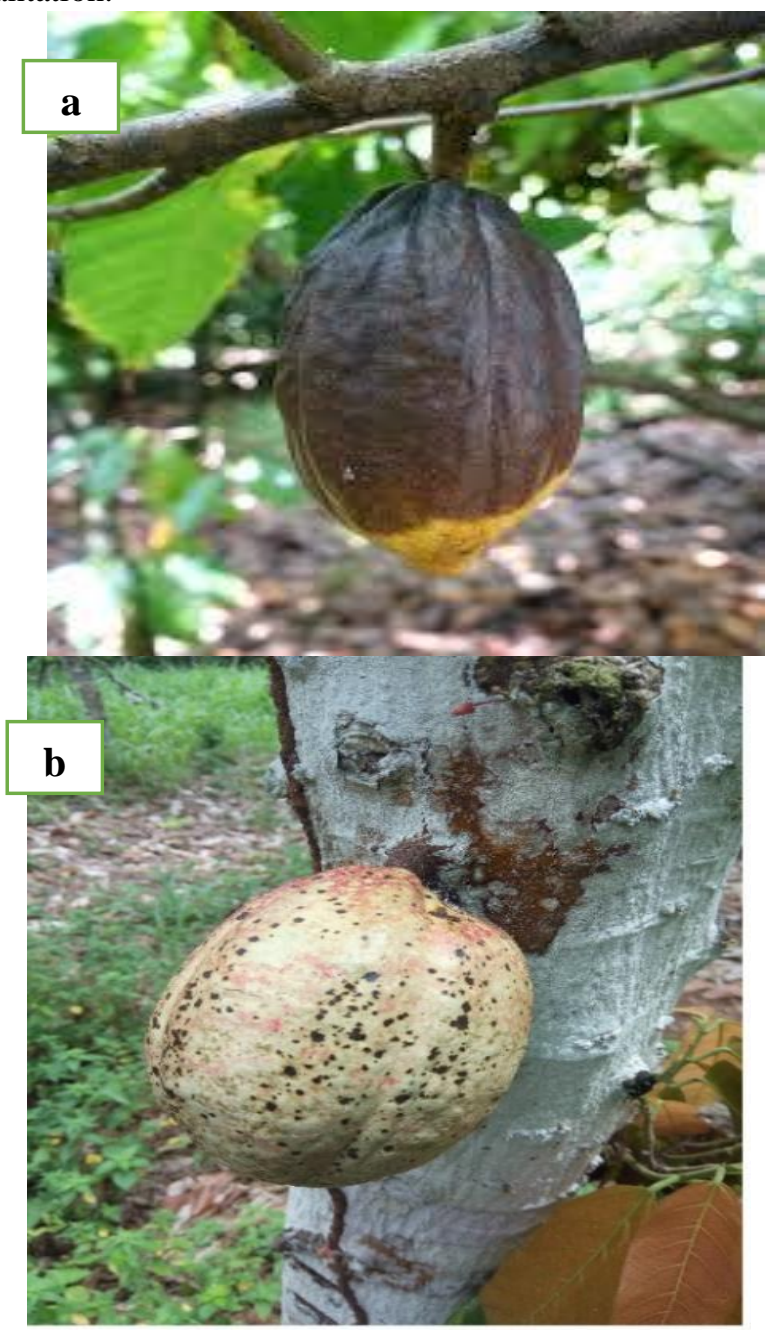

Fig.2Impacts of brown rot (A) and Swollen shoot diseaseon cocoa pod(B) (Photoby Oro,2017).

\section{MATERIALS AND METHODS}

\section{A. Study site}

This study was carried out in $\mathrm{N}^{\prime}$ gouanmoinkro $\left(5^{\circ} 00^{\prime}\right.$ $00^{\prime \prime N}$ North, $6^{\circ} 15^{\prime} \quad 00^{\prime \prime}$ West), village located in the sub-Prefecture of Moronou inthe department of ToumodiFig.33).With an area of about 2,837 $\mathrm{km}^{2}$, this department is located $198 \mathrm{~km}$ from Abidjan, the economic capital and $34 \mathrm{~km}$ from Yamoussoukro, the political and administrative capital of Côte d'Ivoire [16]. Indeed, Toumodi is a department of high cocoa production, it has an estimated annual cocoa production of nearly 9,000 tons[16].

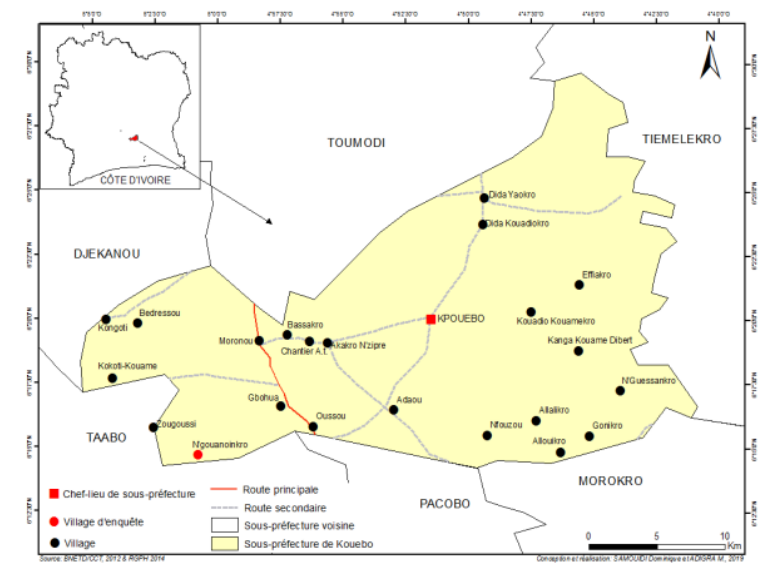

Fig.3Map of the sub-prefecture of Kpouèbo highlighting N'gouamoinkro, experimental site[17].

B.Materials

The plant material consisted of Forastero type cocoa trees at least 10 yearsold. The technical equipment used is: thereference product to be tested Banzaï;SUPERCAOfertilizer; an atomizer to apply the biostimulant Banzaï to cocoa trees; a decameter to delimit the experimental blocks; ribbons and paints to mark the trees.

\section{- C. Methods}

The experimental device (Fig.Fig. 4 consists of a Fischer block composed of six (6) randomized plots denoted T01, T02, T1, T2, T3 and T4 (Fig.

Block1

\begin{tabular}{|l|l|l|l|l|l|l|l|l|l|}
\hline $\mathbf{T}$ & & $\mathbf{T}$ & $\mathbf{T}$ & & $\mathbf{T}$ & & $\mathbf{T}$ & & $\mathbf{T}$ \\
\hline
\end{tabular}

Block 2

\begin{tabular}{|c|c|c|c|c|c|}
\hline $02^{T}$ & 1 & $3^{T}$ & ${ }^{T} 1^{T}$ & $4^{T}$ & 2 \\
\hline
\end{tabular}

\section{Block 3}

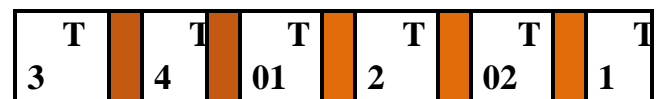

Fig.4 and repeated three times. Each experimental plot is composed of twenty (20) cocoa tests.This device was installed on two sites, a sitewith precedent without fertilizer (DSE) and another device with preceding fertilizer (DAE). The previous no fertilizer consists of a field of cocoa trees that has received no input of fertilizer during the last three years, while the previous fertilizer consists of a field of cocoa trees that has received a supply of fertilizers during the last three years.

- T01 represents the control without application of Banzaï but with a contribution of fertilizer.

○ T02 represents the control without application of Banzaï without fertilizer input.

- T1 is a plot that received three applications of Banzaï with a supply of fertilizer.

- T2 is a plot that has received four applications of Banzaï without fertilizer input.

- T3 is a plot that received three applications of Banzaï without fertilizer input

- T4 is a plot that has received four applications of Banzaï with fertilizer input. 
Block1

\begin{tabular}{|r|r|r|r|r|r|r|r|r|r|}
\hline $\mathbf{0 1}^{\mathbf{T}}$ & & $\mathbf{T}$ & $\mathbf{4}$ & $\mathbf{T}$ & & $\mathbf{T}$ & & $\mathbf{T}$ & $\mathbf{2}$ \\
\hline
\end{tabular}

Block 2

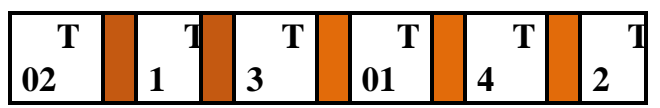

Block 3

\begin{tabular}{|l|l|l|l|l|l|l|l|l|l|}
\hline $\mathbf{T}$ & $\mathbf{T}$ & $\mathbf{T}$ & $\mathbf{T}$ & $\mathbf{T}$ & $\mathbf{T}$ & $\mathbf{T}$ \\
\hline 3 & & $\mathbf{4}$ & $\mathbf{0 1}$ & $\mathbf{2}$ & $\mathbf{0 2}$ & $\mathbf{1}$ \\
\hline
\end{tabular}

Fig.4Experimental device

- D. Observation and data collection

The observations were carried out during nine months (from July to February). They were made on the trunk of each test tree at a height ranging from 0 to 2.35 meters. The data observed were exclusively the number of cherries(immature pod less than $6 \mathrm{~cm}$ in length) produced per test tree. Itis already counted and marked by strings at the level of the peduncle.

- E. Data analysis

The descriptive analysisconsisted in the realization ofhistograms showing the number of cherries produced per plot and per observation time.It also consisted in the realization of boxplots showing the distribution of the cumulativenumber of cherries produced per elementaryplot on all the observations made. The comparative analysis was carried outusing theKruskal-Wallis test,which is an alternative test of the mean comparison test (ANOVA). This test made it possible to compare the average number of cherries produced per elementary plot and per device. Finally, a classification of treatments according to their effectiveness was carried out following the Kruskal-Wallistestwhen it was statistically significant.The statistical analysis was performed using IBMSPSS 20.0software, and R 3.2.5 software.

\section{RESULTS}

A. Cherries produced in the unprecedented fertilizer device (DSE)

Fig. 5 shows the dynamics of evolution of the number of cherries produced per plot as a function of the observation period in the unprecedented fertilizer device (DSE). The highest production of cherries is observed in the month of August. Over the entire observation period,theT4 treatment (four applications of Banzaï with fertilizer) produces the largest number of cherries $(3,638)$.

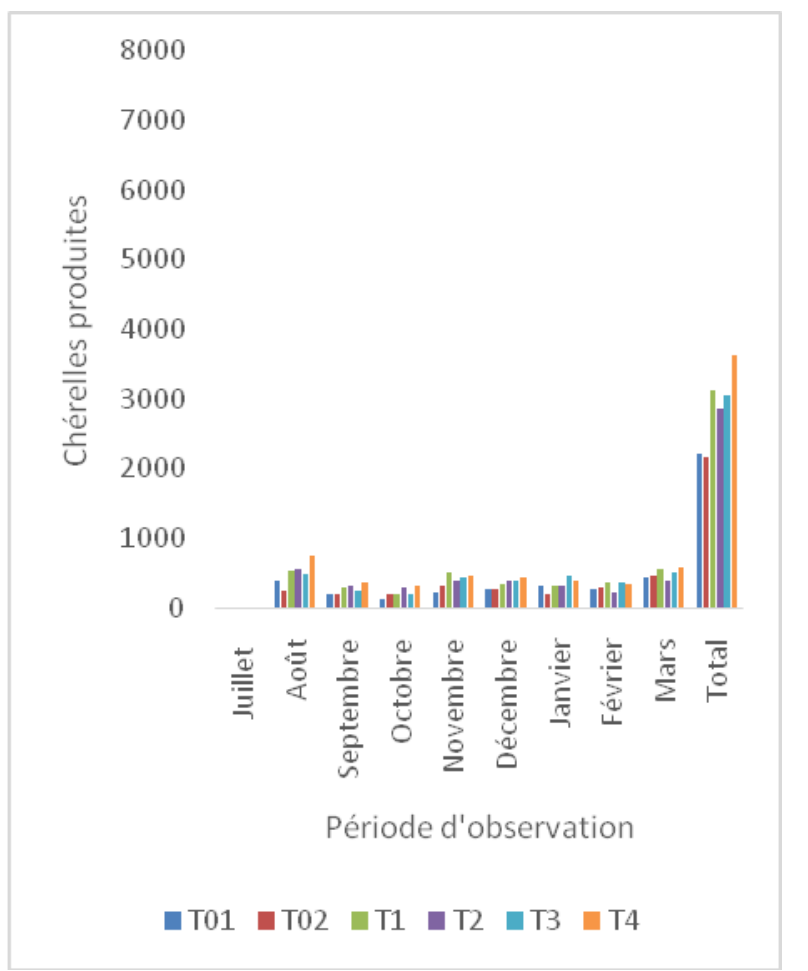

Fig.5Evolution of the number of cherriesproducedper treatment and per month of observation in the DSE device

Fig.6shows theboxplots of the distribution of cherries produced by treatmentin the DSE device.It shows that overall, the number of cherries produced in this device is higher in plots treated with the biostimulant Banzaï than in untreated control plots.However, plot T4 (four applications of Banzaï with fertilizer input) and T1 (three applications of Banzaï with fertilizer input) produced the most cherries in this unprecedented fertilizer device. The Kruskal-Wallis test, used to compare the average production of cherriesper plot,shows that thereis a significant difference $(\mathrm{p}<0.05)$.

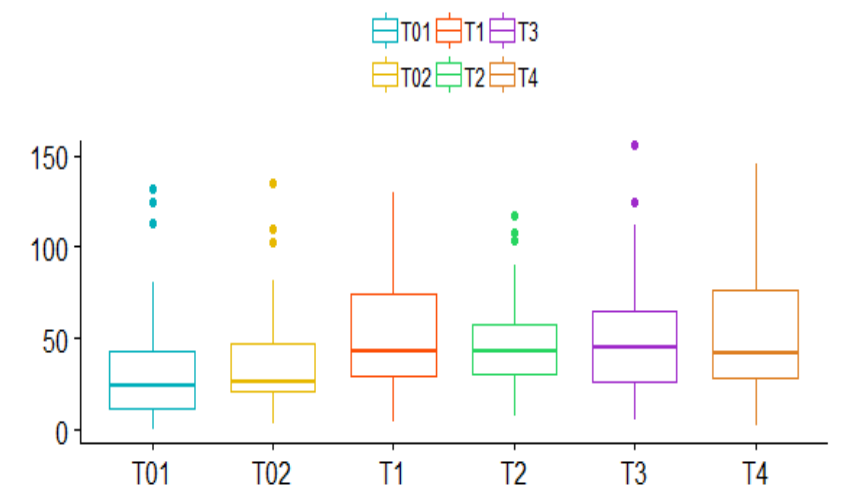

Fig.6Boxplotsrepresenting thedistribution ofthecumulative numberof cherries produced by treatment in the DSE device

The classification of treatments (Table

TableI according to their efficiency in the production of cherries has made it possible to group them into two classesA andB. ClassA, which corresponds to the class of high production of cherries, contained the treatments which respectively produced the most ( $\mathrm{T} 4, \mathrm{~T} 1, \mathrm{~T} 3$ and $\mathrm{T} 2$ ), and class B withthe control plots (T01 and T02) whichhadthe lowest averages of cherries' production. 
the plots in this device with previous fertilizer.

TableII: Classification of treatments according to the averages of cherries production in the DSE device

$\begin{array}{lcc}\text { Treatments } & \begin{array}{c}\text { Cherries } \\ \text { averages } \\ \text { produced } \\ 60,6\end{array} & \text { classification } \\ \text { T4 } & 51,9 & \mathrm{~A} \\ \text { T1 } & 51,0 & \mathrm{~A} \\ \text { T3 } & \mathrm{A} \\ \text { T2 } & 47,6 & \mathrm{~A} \\ \text { T02 } & 36,0 & \mathrm{~B} \\ \text { T01 } & 35,5 & \mathrm{~B}\end{array}$

B.Cherries produced in the device with previous fertilizer (DAE)

Fig.7shows the dynamics of theevolution of the number of cherriesproduced perplot as a function of the observationperiod in the devicewith previous fertilizer(DAE) In general, the number of cherries produced per month is quite close over the nine months of observation with a higher number $(40 \%)$ in the month of August and September. Overall,the plots treated with Banzaï producedagreater numberof cherries than the control plotsoneachmonth of observation in the device with previous fertilizer.

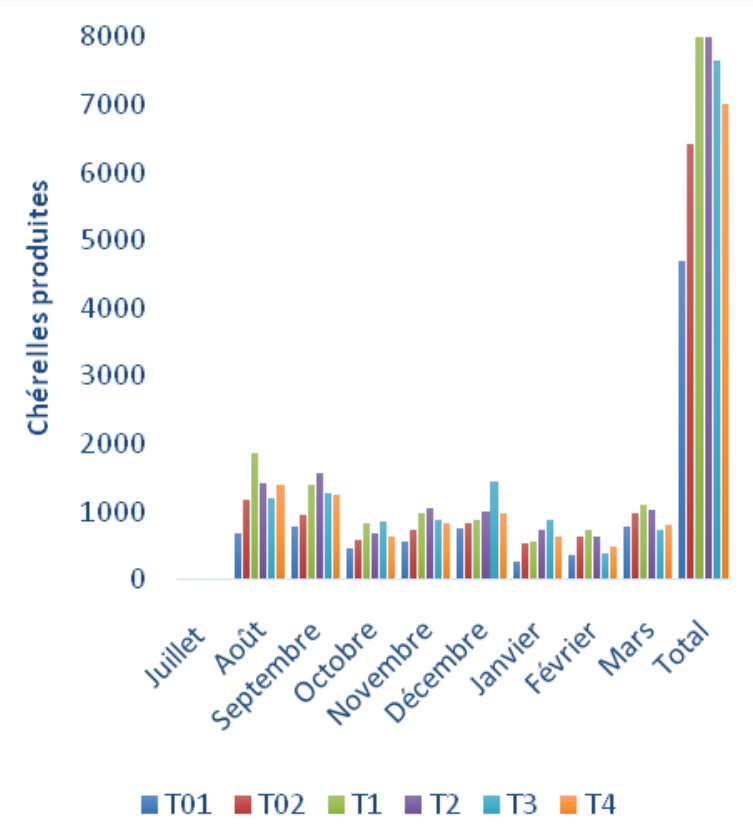

Fig.7Evolution of the number of cherries produced per treatment and per month of observation in the DAE device.

Fig.8Fig.8shows the numberof cherries produced by treatment in the DAE device. The cherries produced are higher in plots with Banzaï treatment than in plots without treatment.Plots T1 (3 applications of Banzaï with fertilizer) and T2 (4 applications of Banzaï without fertilizer)produced the most cherries in this device with previous fertilizer unlike the device without fertilizerwhere plots T4 (4 applications of Banzaïwith fertilizer) and T1(3 applications of Banzaï with fertilizer) had the most cherries product.The Kruskal-Wallis test used to compare the production averages of the cherries shows that there is a significant difference $(p<0.05)$ between

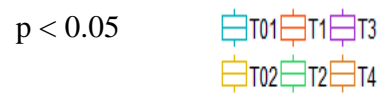

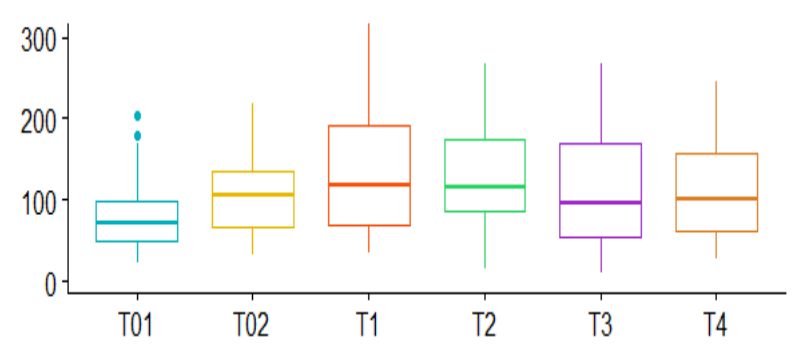

Fig.8Boxplotsrepresenting thedistribution ofthecumulative number of cherries produced by treatment in the DAE device

The classification of treatments according to their effectiveness in the production of cherries (TableTable II has made it possible to group the treatments into two classes $\mathrm{A}$ andB. Class A, of higher efficiency, which contains the plots having respectively the most produced cherries with treatments T1, T2, T3 and T4; and class B of low efficiency with the control plots (T01 and T02) which have the lowest averages of cherries produced by treatment in the device with previous fertilizer (DAE).

Table IIClassification of treatments according to average hopper production per tree in the DAEdevice

$\begin{array}{lcc}\text { Treatments } & \begin{array}{c}\text { Cherries } \\ \text { averages } \\ \text { produced } \\ 139,1\end{array} & \text { cl } \\ \text { T1 } & 135,4 & \text { A } \\ \text { T2 } & 127,4 & \text { A } \\ \text { T3 } & 117,0 & \text { A } \\ \text { T4 } & 110,5 & \text { A } \\ \text { T02 } & 79,4 & \text { B } \\ \text { T01 } & & \text { B }\end{array}$

C. Comparison of the cherries produced in the devices with previous and unprecedented fertilizer (DAE vs DSE)

Fig.9shows the boxplots ofthe distribution of the cumulative numberofcherries produced by device, whether with previous fertilizer (DAE) or unprecedented fertilizer (DSE).It clearlyshows that the plots of the device with previous fertilizer (DAE) have produced more cherries than the plots of the unprecedented fertilizer device. The Kruskal-Wallis test showed a significant difference $(\mathrm{p}<0.05)$ in the production of the cherries between the two devices. Indeed, thenumber of cherries produced is twice as high on the plots of the device with previous fertilizer (DAE) as on the plots of the unprecedented fertilizer device (DSE) (Table

TableI and Table IIIt can be deduced that the previous fertilizer amplifies the effect of the biostimulant Banzaï in the production of cherries. 


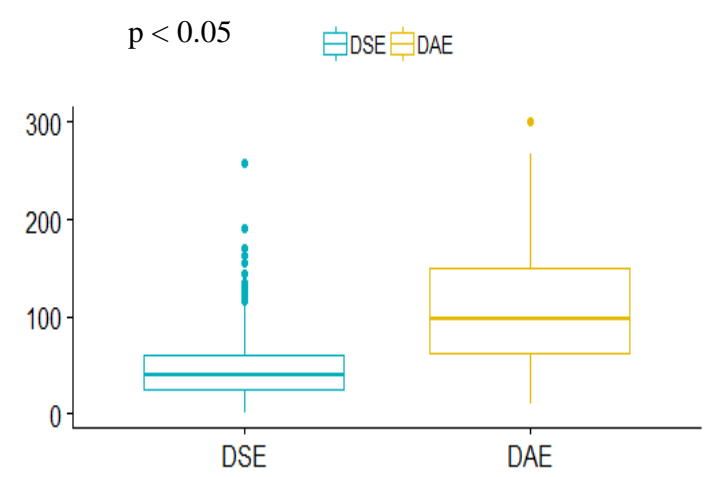

Fig.9Boxplotsrepresenting the distribution of the cumulative number of cherries produced by the DAE and DSE devices.

\section{DISCUSSION}

The evolution of the number of cherriesproduced by treatment during the months of observation showed that the peak of production occurred during the months of August and September. This can be explained by the rainy season from April to June, which favored the peak ofproduction of the cherriesat this time. Indeed,according to the National Agricultural Research Center (CNRA),theproduction ofcherries always reaches its greatest annual increase after periods of rain [18].

The production of cherries by treatment and whatever the device with or without precedent fertilizer showed a significant difference between the plots treatedwithBanzai and the control plots.Indeed, the plots that received the application of Banzai have significantly produced more cherries than the control plots that are without application of the biostimulant. This is in line with the results of Faessel, which states that biostimulants increase the number of fruits by limiting the fall of flowers and fruits[15] These results are also in line with those presented by Oro and his collaborators, on the effectiveness of thebiostimulant Banzaï in the production of cherries in a context of Swollen Shoot Disease in the department of Soubré [19].In addition, the biostimulant promotes flowering, limits the fall of flowers while stimulating the vigour of the cocoa tree and its fruits against external diseases and stresses [14; 20-21]. Indeed, biostimulants contain extracts of algae that act on the natural physiological processes of the plant by promoting the flowering and ripening of fruits [22-23].

The comparative analysis of the production of cherriesbetween the device without prior fertilizer (DSE) and the device with previous fertilizer (DAE) showed a significant difference. Indeed, plots with previous fertilizers have a production of cherries significantly higher than that of plots without previous fertilizer. This can be explained by an accumulation of fertilizers in the soil that improves the productivity of cocoa trees. Our results areconsistent withthose of Goulet, which shows that the accumulation of fertilizers in the soil improves the production yield of cherries and pods [24]. This, which may therefore explain the fact that the fertilizer used during this experiment had no significant effect in improving the production ofcherries and in particular in the device with previous fertilizer, in the unprecedented fertilizer, it is nevertheless the plots with fertilizer and Banzaï that have been arithmetically the most productive. These data are also in line with those presented by Effendy and his collaborators who have proved that the lack or misuse of fertilizers in rural Indonesian cocoa plantations is an important factor in the decline in the incomes of growers and in the decrease in the yield of these plantations [25].

\section{CONCLUSION}

At the end of this study, it appears that the application of Banzaï on plots has a positive effect on the production of cherries by causing a significant increase in production of the order of 40 to $50 \%$ in plots treated with the biostimulant Banzaï comparedto controlplots without application of biostimulant. With regard to the effect of the previous fertilizer, it should be noted that the plots with previous fertilizers capitalize doubly morethe effect of the biostimulant by the reinforced and accumulatedfertilization of the soilthus resulting in a significant improvement in the production of cocoa trees.

\section{REFERENCES}

[1] Tixier C. "From the cocoa tree to chocolate: journey to the source of aromas and flavors." Herbal medicine (2013). 11 79-84.

[2] Mossu, G. Le cacaoyer. Maisonneuve and Larose, Paris, $1990.160 \mathrm{pp}$.

[3] Lachenaud Philippe. Guide d'identification des cacaoyers CIRAD-BIOS, 2014, Upr 106, p.12.

[4] International Cocoa Council Organization (ICCO). Quarterly Bulletin of Cocoa Statistics, 2018. Vol. XLIV, No. 3, Cocoa year 2017/18

[5] World Bank. "In the land of cocoa, how to transform Côte d'Ivoire." World Bank 2019, NW Washington, DC.

[6] Kanga N. Analysis of the determinants of adoption of certificates in the cocoa sector in Côte d'Ivoire, Diploma in advanced agronomy,2018, FelixHouphouëtBoigny National Polytechnic Institute of Yamoussoukro.p73.

[7] Coulibaly K, Kébé B, Aka A, Kouakou K, N'Guessan W, Tahi G.M, Kassin K.E, Guiraud S.B, Assi M, Koné B, N'Guessan K Fight well against the brown rot of cocoa pods in Côte d'Ivoire. Cocoa technical sheet $n^{\circ}$ 6, CNRA report 2017. p.1-2.

[8] Despréaux D., Clément D., Partiot M. La pourriture brune des cabosses du cacaoyer au Cameroun: mise enévidence d'un caractère de résistance au champ. Agronomy, EDP Sciences 1989. pp: 683-691.

[9] Janny G., Barbara J.et Flood J. Discovering cocoa, Caba. Biosciences 2003. 123p.

[10] Kouamé Y. Control of cocoa pests: case of drillers. KMS-Côte d'Ivoire 2013. Article No. 9103, 2p.

[11] Franck Zokou ORO, Hermann-Desiré LALLIE, Jesus Inza FOFANA, Pacôme Bi-ZAOULI and Hortense Atta DIALLO Impact of biostimulant Banzaï on the production of pods in the case of swollen disease shoot of cocoa trees in Côte d'Ivoire. Africa Sciences 16, 2020. Issue 5: 93-105.

[12] N'goran K. Reflections on a Sustainable Cocoa Production System: Case of Côte d'Ivoire. National Zoo. 1998 IDEFOR-DCC. 28p.

[13] Flood J, Guest D, Holmes K, Keane P and Sulistyowati E. Cocoa under attack. In Cocoa Futures. CABI-FEDERACAFE, Chincina, Colombia. 2004. 164pp.

[14] European Biostimulants Industry Council (EBIC) Promoting the biostimulant industry and the rule of plant biostimulants in making agriculture more sustainable. 2014, (http://www.biostimulants.eu/).

[15] Faessel L, Gomy C, Nassr N, Tostivint C, Hipper C, Dechanteloup A. Agricultural stimulation products aimed at improving the biological functionality of soils and plants. Review of available knowledge and policy recommendations. Bio by Deloitte and RITTMO Agri-environment for the Ministry of Agriculture, Agri-Food and Forestry. 2014. 148 p.

[16] Agence Ivoirienne de Presse (AIP). Monograph of the department of Toumodi. 2013. Abidjan.Net. Visit date 22/12/2018. 5p. 

in the Locality of N'gouanmoinkro in the department of Toumodi, Central Côte d'Ivoire

[17] General Population and Housing Census (RGPH). Directory of localities: Aries Region. INS 2015. 40p.

[18] Centre National de Recherche Agronomique (CNRA). Well grow cocoa in Côte d'Ivoire. Cocoa data sheet. 2009. pp. 1-4.

[19] Franck Zokou Oro, Hermann-Desiré Lallie, Jesus Inza Fofana, Pacôme Bi-Zaouli, and Hortense Atta Diallo. Efficiency of Banzai Biostimulant on the cherries production in healthy and cocoa trees affected by swollen shoot virus: A case study at Petit-Bondoukou Côte d'Ivoire. International Journal of Advances in Scientific Research and Engineering (IJASRE). 2020. Vol 6 (1), January-2020, pp 108-119.

[20] Callivory. Biostimulant Banzaï. Callivoire Report 2017. p-2.

[21] Manuele Ricci, Lorraine Tilbury, Bruno Daridon, Kristen Sukalac. General Principles to Justify Plant Biostimulant Claims. forehead. Plant Sci 2019. $10: 494$

[22] Bulgari Roberta, Trivellini Alice, Ferrante Antonio. Effects of two doses of organic-extract based Biostimulant on Greenhouse Lettuce grown under increasing $\mathrm{NaCl}$ concentrations. forehead. Plant Sci. 2019, 9: 1870.

[23] Mannino Giuseppe, Campobenedetto, Vigilante Ivano, Contartese Valeria, Gentile Carla and Bertea Cinzia M. The application of a plant biostimulant based on seaweed and yeast extract improved tomato fruit development and quality. Biomolecules 2020;10(12): 1662.

[24] Goulet M, N'Dayegamiye A and Laverdière M. Soil sciences in the 21st century. Centre de recherche et d'expérimentation en sols, Ministère de l'Agriculture, des Pêcheries et de l'Alimentation du Québec, 2700 Einstein, Sainte-Foy, Québec, Canada. 1997. G1P 3W8. 110p.

[25] Effendy, Pratama Fardhal, Rauf Rustam Abdul, Antara Made, Basir-Cyio Muhammad, Mahfudz and Muhardi. Factors influencing the efficiency of cocoa farms: A study to increase income in rural Indonesia. Plos One 2019. 14 (4): e0214569. 